\title{
HYBRID WARFARE AND THE RUSSIAN FEDERATION INFORMATIONAL STRATEGY TO INFLUENCE CIVILIAN POPULATION IN UKRAINE
}

\author{
Aurelian RAȚIU \\ "Nicolae Bălcescu" Land Forces Academy, Sibiu, Romania \\ ratiu.aurelian@armyacademy.ro \\ Alexandra MUNTEANU \\ "Nicolae Bălcescu" Land Forces Academy, Sibiu, Romania \\ sandamunteanua@yahoo.com
}

\begin{abstract}
The conflict in Ukraine is largely considered to be a strong example of hybrid warfare, where the Russian Federation is using hybrid tactics to influence Ukraine and especially the civilian population. This paper focuses on answering the research question, how is the Russian federation using its informational warfare to influence civilian population in Ukraine? In this respect we will use the ASCOPE (Area, Structures, Capabilities, Organizations, People and Events) analysis, in order to determine trough each field, the methods in which Russia seeks control over the specific area and manipulate how the civilian population of Ukraine perceives the cause and events within their country.
\end{abstract}

KEYWORDS: hybrid warfare, information warfare, civilian population, ASCOPE methodology, propaganda

\section{Introduction}

There are a lot of different theories, between military analysts and schools, about how the future of war will look like. One of the "new wars" school characterizes the war as being shaped by the process of globalization, other authors stated that the contemporary war in Afghanistan and Iraq represents the new "fourth generation" in warfare, which performs an evolution in insurgency and attempts to erode the political will to fight of the enemy. But there is another important school that thinks like the hybrid warfare is the future. Combining conventional, irregular and informational warfare, the hybrid warfare exploits the vulnerabilities of the potential opponent and, even more, seek to obtain support of the civilian population in a specific region, in order to ensure the maximum success with the minimum effort. Being in the informational era, the greatest consideration is given to the "Information warfare", materialized in electronic warfare, cyber-attacks, deception and psychological operations.

Ukraine is the second largest country in Europe, after Russia, and its current population is about 46 millions. It is reasonable to say that its name reflects its character, Ukraine meaning borderland. Ukraine has a tumultuous history with a continuous struggle in finding its identity. Only after the dissolution of the Soviet 
Union at the end of the Cold War in 1991, Ukraine could gain its independence. Its rapid evolution has surprised the international community, establishing a political identity separated from Russia and adopting a new Constitution and a democratic system. By leaving the Soviet Union and declaring independence, Ukraine made Moscow lose control over the other Republics and, therefore, collapse, 15 new states appearing on the map. Accordingly, the existence of an independent Ukraine discouraged hegemonic tendencies and encouraged the approaching of a balanceof-power in the region.

Many authors describe the condition of Ukraine beginning with one word: statelessness. Orest Subtelny, a UkrainianCanadian historian, stated that the history of Ukraine is stressed in two themes: the statelessness and the modernization. The statelessness was described by the author as: "the frustration of the Ukrainians' attempts to attain self-government is one of the key aspects of their historical experience. Therefore, the Ukrainian past is largely the history of a nation that has had to survive and evolve without the framework of a full-fledged national state" (Subtelny 2000, p. xv). Also another 2 authors affirmed that "The reason most frequently given for Ukraine's perennially undefined condition is statelessness. For much of their history, Ukrainians have been ruled by others. As parts of the Polish or Habsburg or Soviet mega states, Ukrainians had little opportunity to develop a distinctive high culture, define their common interest, develop a sense of national identity, or even delineate their borders" (Wolchik \& Zviglyanich, 2000, p. 2).

"Ukraine is a multi-ethnic, multilanguage and multi-culture country" (Gulamov, 2014), thereby, history of Ukraine has unfolded with a deep division regarding political, economic and linguistic domains between ethnically Ukrainians and ethnically Russians.
Although there are numerous discussions between scholars and military thinkers regarding whether the Russian information warfare is truly "a new way of war", a certain aspect of Russian strategy is that "information now has primacy in operations, while more conventional military forces are in a supporting role" (NATO StatCom COE, 2015). Therefore, the main battle space, from the Russian perspective, is in the people's mind, the necessity for hard military power being minimized.

In order to create the proper environment for Russia, Kremlin's propaganda machine works in both ways: for foreigners and for Russian population. The former is used in order to propagate the idea that Russia is not worse than Western countries and, also, to give the impression that Russia is prepared for war. The latter, is persuaded to believe that the United States is the enemy responsible for all internal problems, Putin being presented as the only leader capable of leading Russia against this threat.

The principal focus of Moscow's campaign are the ethnic Russians living abroad, which need the protection of "Mother Russia". Rod Thornton identified two goals of the Russian information campaign: "to instil in these compatriots Russian what has been called a soft loyalty to Russia through an emphasis on cultural, linguistic and ideological links and to instil fear among these target groups that their host government will one day turn on them" (Thornton, 2015, p. 43). Having great influence on their thinking, they will become a medium of communication and will eventually convince on non-Russians to adopt the same beliefs.

2. The ASCOPE Analysis and Russian Informational Strategy

Military structures in the current operations (irregular, hybrid) have different methods, mechanisms or methodologies in the decision making process and missions planning. To provide an analyzing framework 
they use, for example, JIPOE - Joint Intelligence Preparation of the Operational Environment, or PMESII-PT (Political, Military, Economic, Social, Information, Infrastructure, Physical environment, and Time), and for a broader understanding specific aspects regarding the civil population from theatres of operations, leaders use methods such as ASCOPE - Area, Structures, Capabilities, Organizations, People, and Events.

If the ASCOPE model becomes for some reasons not broad enough or simply for a further understanding, planners use the ASCOPE/PMESII model, a matrix crafted by applying every field of the ASCOPE analysis to the six operational domains: Political, Military, Economic, Social, Infrastructure and Information. An analysis encompassing the entire ASCOPE/PMESII analysis would probably fill too many pages. Due to this reason, I will further restrict ours research to the information domain, populating every category of the ASCOPE model.

\subsection{Areas}

Regarding the Ukrainian-Russian issue, there is a pattern between native speakers, linguistic division, religion and political preferences. Ukraine is divided two main parts (mainly referred to as "the East-West dichotomy"):

In West and Center: ethnically Ukrainians speaking the official language, believing in the Ukrainian Orthodox Church of Kiev Patriarchate, and aiming at joining the European Union and NATO;

- In East-Center, East and South: a considerable majority of ethnically Russians, speaking mainly the Russian language, believing in the Ukrainian Orthodox Church of Moscow Patriarchate, aiming to strengthen the relations with Russia.

Ukraine consisted of 24 regions, two cities with special status (Kiev and
Sevastopol) and the Autonomous Republic of Crimea, according to the constitution. Geographically speaking, Ukraine is divided in regions (oblasts and districts) and places of settlements (towns, cities and villages). Although its population was about 45 million people by the beginning of 2014, only 5 cities have their population greater than one million people (Haub, 2014).

Of an particularly interest is Crimea, which, after Ukraine gained its independence in 1991, was declared the Autonomous Republic of Crimea and Sevastopol retained special status within Ukraine. In 1997 Ukraine signed two friendship treaties which allowed Russia to base its fleet in Crimea, having its headquarters in Sevastopol, Russia agreeing to write off Ukraine's debt for oil. In March 2014, a much disputed voluntary referendum on Crimea joining Russia was held.

Another important area is Donbass which consists of Donetsk and Luhansk regions of eastern Ukraine. The demonstrations of pro-Russians separatists in Donbass, declaring independence from Ukraine short after the Crimea annexation, turned into an armed conflict between the Ukrainian government and the separatists of the self-proclaimed Luhansk and Donetsk People's Republics. In September 2014, the representatives of Ukraine, Russia, DPR and LPR signed an agreement in order to stop the war in Donbass region, the Minsk Protocol, which failed and was followed by a summit in Minsk in 2015 with a new package of measures. The Donbass region is now considered as "special status" (They would have the right to hold their own elections and those who fought against the Ukrainian army would receive amnesty).

Since the beginning of its independence in 1991, Ukraine has faced a great challenge in its struggle to build a national identity and unite the country in spite of its ethnically diverse regions. The recent events demonstrated that this division between the west and the east can cause even more destabilization. 
In conclusion, the area is very important in Russia's influence analysis. Firstly because Ukraine itself stands between EU/NATO and Russian Federation and this will have implications in the stability of the state. Secondly, the existence of two rival groups with different language, culture, beliefs and aspirations that perhaps will hamper the development of the country. The Russian Federation is taking advantages of the situation of Ukraine, exploiting it through its own population from this area.

\subsection{Structures}

Considering the informational warfare that occurs in Ukraine, of a particular interest is the structure of this country's media. In this context, two main aspects were considered:

- Firstly, how is the media system working in Ukraine: the most used medium for keeping up with the events, the ownership structure, the laws regarding mass-media and how they are applied, who is in charge with controlling if those laws are applied.

- Secondly, how does Russia interfere in this informational system: the presence of Russian manipulation in media sector, the language issue, countermeasures adopted against the Russian influence.

The main information medium in Ukraine is television. "According to a survey conducted in March 2016 in Kiev by the Gorshenin Institute, a Ukrainian think tank, 88 percent of Ukrainians mainly use television to stay informed about current affairs" (Pörzgen, 2016). One of the serious problems is that private channels are being used for business and political interests by oligarchs. The Ukrainian population does not know who the owners of TV channels are and they show little interest in having access to such information.

The online media has recently grown in importance between Ukrainians giving the fact that users are provided with information up to date and for free. But, the Internet and social media have been the perfect space for spreading limitless fake photos, videos and reports.

Because of the economic crisis, newspapers are used only by 12.5 percent of Ukrainian citizen, online versions having more success. Nowadays, the newspaper market of Ukraine is facing two problems: the slow distribution of newspapers through postal service and the high cost of paper needed for newspapers, which is imported from Poland and Russia.

The recent confrontation between Russia and Ukraine gave the media even a greater level of influence on Ukrainians used it to keep up with current internal affairs of the country. The credibility of Ukrainian media is increased in the Western region, while the Russian media is more intense in the East and South. "The strong competition coming from Russian newspapers, radio, and TV channels weakens the Ukrainian media market and hampers its development" (Ryabinska, 2011, p. 5). The Ukrainian independent media has difficulties in its establishment because the Russian media still strongly influences it, many movies, newspapers and online media having both Ukrainian and Russian content.

Concluding, the structure of Ukrainian media system, although it is true that it had to face a hard transition from the Soviet monopoly period, is still far from being comparable to the standards that a democratic society requires. A country with 45 million people could have a real large and dynamic media market, but the low budget makes it dependent and vulnerable.

\subsection{Capabilities}

In fighting the war of information with Moscow, the capabilities of Ukraine's media might be limited but not eradicated, and it still continue to demonstrate that the situation in Ukraine is not "simplified and painted in black and white, where the 
diabolic West is black, and Russia is white" (Darczewska, 2014, p. 27) as Russian propaganda pretends.

Further, two main aspect was considered regarding the Russian propaganda: firstly, its strengths and impact on Ukrainian population and, secondly, its weaknesses and the ability of the Ukrainian media to exploit them.

The Russian propaganda has high volumes and is distributed through a large number of channels. This propaganda includes "text, video, audio, and still imagery propagated via the Internet, social media, satellite television, and traditional radio and television broadcasting" (Christopher \& Miriam, 2016, p. 2). Also, Russian propagandists control thousands of fake accounts on different social networks used by Internet "trolls" in order to attack counterRussia information on news and websites.

The variety of sources represents a key of success in Russian propaganda. According to Christopher \& Miriam (2016, p. 2), "multiple sources are more persuasive than a single source, especially if those sources contain different arguments that point to the same conclusion, and, also, receiving the same or similar message from multiple sources is more persuasive". Besides, the quoted authors underline that when the interest of consumers is low, the number of supporting arguments of a message is more persuasive than the quality of those arguments. In addition, the views of other plays an importing role in the credibility of sources, people tending to perceive a source as credible of others perceives it as credible. In Russian propaganda, the quantity is important due to four reasons: it consumes the attention of the audience, it eliminates the competition by overwhelming it with disagreement, the level of exposed audience to the message increases with the number of channels, and the credibility is increased by broadcasting the same message through multiple sources and mechanisms.
Russian propaganda is repetitive and rapid. It responds to events very quickly, disseminating the first "news" of an emerging event in a manner that best support Russian interests, although this news might not be accurate. In order to pursue audience to accept the message as true, they repeat it, creating "the illusory truth effect". "Repetition leads to familiarity, and familiarity leads to acceptance" (Christopher \& Miriam, 2016, p. 4).

Also, Russian propaganda uses manufactured information: edited photos, paid actors to play as victims, faked scenes and sources. While some Russian news might contain half-truths, other might be completely false, this representing the difference between disinformation and misinformation.

Another distinctive feature of Russian propaganda is that it "is not committed to consistency", materialized by changing event from one day to another. Although it might seem contradictory, this inconsistency can have a greater persuasive impact because audience perceive it as "having given greater consideration to the topic" (Christopher \& Miriam, 2016, p. 8) and therefore the level of the source credibility increases.

The capabilities of Ukraine are restrained in comparison to its big neighbor, and the lack of financial support makes the Ukrainian media resort to the help from oligarchs and politicians, which has never been for free. In the context of an information warfare with Moscow, Ukraine must find resources to strengthen its media and gain the trust of its own citizen, regardless their ethnicity, so they would not feel the need to use the Kremlin's version.

\subsection{Organizations}

Organizations play an important role in the populace's life because they influence and interact with people. Among them, the most significant organizations used by Kremlin in Ukraine, more or less directly, are 
non-governmental organizations (NGOs), the church, think tanks, large companies and political parties. These are the means of the Kremlin's soft power, used to influence global opinion. "Putin's Russia cares very much about ideas-funding and engaging with intellectual influencers, think tanks, political parties, and religious and social movements across the world" (Pomerantsev \& Weiss, 2014, p.18).

Approximately 50.000 NGOs and charity organizations are registered in Ukraine. Many of them receive funding from foreign governments, such as the big neighbor Russia. "Moscow provides an estimated US $\$ 130$ million a year to proKremlin NGO projects outside Russia, mostly in former Soviet and Balkan countries" (Russell, 2016, p. 3). In return, the Russian government controls the activity of these NGOs, mostly by determining them to undermine the cooperation of Ukraine with the West.

Besides these large organizations, the interests and culture of Russia are shared also through a number of very active think tanks, who develop studies and publish many articles, including in English language.

The political parties played an important role in the Ukrainian protests. The political landscape of Ukraine is reflected in the division between Russia and the West, the political camp being divided in two major movements: the pro-Western and pro-European liberal group (represented by blocs such as Our Ukraine, UDAR and Fatherland) and the proRussian, Eurosceptic, anti-American and anti-liberal group represented by the Opposition Bloc, the Party of Regions and the Communist Party of Ukraine.

Having direct connections with the civilians, organizations have always been a convenient tool for Kremlin's propagandist objectives. Financing them and keeping close relationships with their leaders, Putin successfully pursued numerous NGOs, big companies and churches to shares Moscow's message.

\subsection{People}

Oleg Bazaluck (2016, pp. x-xii) comprised few aspects of Ukraine that surprised the world community: backward economy, neglect for the nation's health (Ukraine having the highest mortality in Europe), the low level of the population's education (diplomas do not correspond to world standards), and the backward scientific and technical base.

Moreover, war involves people; this is what makes it so complex. But when it comes to an information warfare, the situation gets even more complicated, the main goal being the influence of population's attitude and beliefs. Presidents, oligarchs, priests, politicians, well-known journalists succeed in doing this in an effective manner.

Also, many businessmen got rich in the 1990s from gas trade with Russia. They were buying gas at low price and selling at a different price at free markets (the practice is known as "sitting on the pipe"). The problem with the oligarchs is that they are omnipresent through their power and wealth, being important players in politics and economy. They succeed in defending themselves by controlling media outlets and parliament members. The ongoing war with Russia makes them safe from the danger of "deoligarchization", because such an attempt would led to a political conflict and generate internal destabilization in Ukraine.

\subsection{Events}

Ukraine has not had an easy path throughout the history. The programs against Jews, the Great Famine, the Nazi massacre of civilians at Babi Yar and the Chernobyl nuclear disaster are the tragedies that resulted in millions of deaths each and left the population face with state support dependence, growing unemployment, environmental damage, rising cost of health care and an aging populace. As Marta Dyczok associate professor at University of Oxford said “Ukraine's social problems 
are not unique" (Dyczok, 2013, p. xvii), but Ukraine had to endure all these issues during its process of shifting to an independent state. Although the history is said to be the root of the current crisis, especially the common history of Russia and Ukraine, the purpose of this category frames only the events of the independent Ukraine.

The Orange Revolution is believed to be "the first example of an Internetorganized mass protest" (McFaul, 2005, p. 12) its success being achieved due to the use of Internet information. Lysenko and Desouza stated in their case study about the Orange Revolution: "Since the main Ukrainian traditional mass media were controlled either explicitly or implicitly by the regime, civic groups started using the Internet as an alternative channel for critical information" (Lysenko and Desouza, 2010).

Another astonishing Ukrainian event was Yushchenko's assassination attempt through dioxin poisoning, during his election campaign in 2004, which left him disfigured and shocked the whole international audience. Yushchenko commented on one of his many interviews about the accident: "My poisoning took place because I had started taking steps towards the European Union. We have a neighbor who does not want this to happen" (Sengupta, 2015).

The Maidan demonstrations began, on November 21, with the Facebook post: "I am going to the Maidan. Who's coming with me?" They were mainly youth, alerted by social networks and text messages. Even the name of the revolution is said to have begun with a hashtag used on Facebook and Twitter. The event was followed and 'liked' on social media by thousands of people. Online interviews were used to feed the spirit and activism at Maidan.

The Euromaidan revolution had an important online dimension: the activists were sharing information, forums were full of discussions, the Internet was filled with live videos, and the international society followed the event on social media. "Live video streaming over the Internet became a key instrument for witnessing remotely" (Bohdanova, 2015). But the Russian influence tried to control online media by attempting to block the access to proUkrainian sources and by requesting information about the Euromaidan protesters.

The annexation of Crimea in 27 February 2014 using only sixty men with Kalashnikovs demonstrated the effectiveness of Russia's propaganda machine. The effort to build a positive sense of Russian identity along with convincing the inhabitants of Crimea and Eastern Ukraine that the Ukrainian nationalists had planned to kill Russian speakers succeeded to make the Crimean populace wish the returning to Mother Russia.

Another act of drama was the conflict in Donbass, the region with the second largest number of ethnic Russians and Russian-speakers in Ukraine. Many media outlets tried to frame the war in Donbass. The Russian channels broadcasted fabricated stories, fake images and misinformation in order to "legitimize" Russia's actions in the region. Moreover "military maneuvers appear to be planned for Russian cameras - with the primary aim of spreading information rather than engaging in military warfare" (Pomerantsev \& Weiss, 2014, p. 30).

\section{Conclusions}

In wars, as well as in hybrid warfare, the operations are conducted through mission command, which is tied to the human terrain. It is reasonable to say that human is the core of war and the complexity of war is mainly given by the enigmatic nature of humanity.

The success of a mission relies on the level of understanding that the leader achieves by integrating techniques for analyzing multiple aspects of the human 
terrain into the military decision making process. The understanding of the human terrain is challenging because the values differ from one society to another and they change over time. Yet the leader should adapt fast and show flexibility.

Russia did demonstrate the impact that soft power has on the result of a conflict when managing to annex a territory without firing a gun. The media sector played and is still playing a great role in keeping a majority of Ukrainian under the Russian information space. As highlighted in the analysis, the information strategy of Russia is reflected in a wide range of tools, every tool having its methods and its results, but all integrated together succeeding to achieve the main objective of creating instability in Ukraine. Following each step of this analysis, it can be concluded that even the information warfare is hybridized in Russia's strategy, considering the numerous and varying tools blended.

Ukraine is not only a transit country between the West and Russia, but also its territory is deeply divided into two big groups regarding ethnicity and language. This is the weakness that Russia seeks to exploit to maximum using propaganda for shape opinions and defense its actions. The corruption and oligarchic system of media is reflected in the content of publications. The insufficient development of the media system in Ukraine makes the country unable to proper react at the Moscow's well-organized propaganda. In this information warfare, the propaganda works also through NGOs, compatriots' organizations, churches, considering that civilians trust on them.

Not even one important event in Ukrainian's life was deprived by Moscow's implications and Russia's propaganda reached large audience and covered, misled or faked the information in order to best suite its interests. Using the excuse of protecting its compatriots abroad, Putin invaded and annexed another country's piece of territory. But the real success was the fact that he did this "with the desire of its inhabitants". This is how far Kremlin's propaganda can go. After all, the Ukrainian crisis turned out to be more about Russia's future rather than Ukraine's.

\section{REFERENCES}

Bazaluk, O. (2016). Corruption in Ukraine: Rulers' Mentality and the Destiny of the Nation, Geophilosophy of Ukraine. Newcastle upon Tyne, UK: Cambridge Scholars Publishing.

Bohdanova, T. (2015). How Euromaidan and War with Russia Have Changed Ukraine's Internet. Stop Fake.org - Struggle against fake information about events in Ukraine, available at: http://www.stopfake.org/en/how-euromaidan-and-war-with-russia-have-changed-ukraines-internet/, accessed on: 2 May 2018.

Christopher, P., \& Miriam, M. (2016). The Russian "Firehose of Falsehood" Propaganda Model. Santa Monica, USA: RAND Corporation.

Darczewska, J. (2014). The Anatomy of Russian Information Warfare: The Crimean Operation, A Case Study. Warsaw, Poland: Centre For Eastern Studies.

Dyczok, M. (2013). Ukraine: Movement Without Change, Change Without Movement. Abingdon: Routledge Taylor \& Francis Group.

Gulamov, S. (2014). Understanding National Identity: Ukraine's Ethnic Diversity, available at: https://www.eastwest.ngo/idea/understanding-national-identity-ukraine\% E2\%80\%99s-ethnic-diversity 
Haub, C. (2014). Ukraine's Demographic Reality. Washington, DC: Population Reference Bureau, available at:https://www.prb.org/ukraine-population/, accessed on: 2 May 2018]

Lysenko, V., \& Desouza, K. (2010). Role of Internet-bazed Information flows and technologies in electoral revolutions: The case of Ukraine's Orange Revolution. First Monday Journal, Vol. 15, No. 9, available at: http://firstmonday.org/ojs/index.php/ fm/article/view/2992/2599, accessed on: 12 September 2018.

McFaul, M. (2005). Transitions from Post Communism. Journal of Democracy, Volume 16, no. 3. Baltimore, United States: Johns Hopkins University Press.

NATO StratCom COE - NATO Strategic Communications Centre of Excellence (2015). Analysis of Russia's Information Campaign against Ukraine, available at: file:///C:/Users/asus/Downloads/russian information campaign public 12012016fin.pdf, accessed on: 2 May 2018.

Pomerantsev, P., \& Weiss, M. (2014). The Menace of Unreality: How the Kremlin Weaponizes Information, Culture and Money. The Interpreter. New York: The Institute of Modern Russia, Inc.

Pörzgen, G. (2016). Facing Reality after the Maidan: The Situation of Journalists and Media in Ukraine. Reporters without Borders, available at: https://rsf.org/en/reports/facingreality-after-euromaidan-rsf-presents-new-report-ukraine, accessed on: 12 September 2018]

Russell, M. (2016). Russia's information war: Propaganda or Counter-propaganda? European Parliament Think Tank, European Parliamentary Research Service.

Ryabinska, N. (2011). The Media Market and Media Ownership in Post-Communist Ukraine: Impact on Media Independence and Pluralism. Problems of Post-Communism Journal, Volume 58, no. 6.

Sengupta, K. (2015). Viktor Yushchenko: "Every politician in Ukraine who turns to the West is in danger". Independent, Wednesday 14 October 2015, available at:https://www.independent.co.uk/news/people/viktor-yushchenko-every-politician-inukraine-who-turns-to-the-west-is-in-danger-a6694311.html, accessed on: 12 September 2018].

Subtelny, O. (2000). Ukraine: A History. Toronto: University of Toronto Press.

Thornton, R. (2015). The Changing Nature of Modern Warfare. The RUSI Journal, Vol.160, No.4.

Wolchik L. S., \& Zviglyanich V., (2000). Ukraine: The Search for a National Identity. Lanham: Rwoman and Littlefield Publisher Inc. 